\title{
Postmodern Strategies in Ian McEwan's Major Novels
}

\author{
Jie Han, Zhenli Wang \\ Foreign Language Department, Baoding University, Baoding, China \\ Email: hanjie198262@163.com
}

Received 20 July 2014; revised 21 August 2014; accepted 17 October 2014

Copyright (C) 2014 by authors and Scientific Research Publishing Inc.

This work is licensed under the Creative Commons Attribution International License (CC BY). http://creativecommons.org/licenses/by/4.0/

c) (i) Open Access

\begin{abstract}
Ian McEwan, together with Martin Amis is now the best-known and controversial contemporary British novelist. McEwan seems to be interested in the relationship between reality and imagination, history and fabrication in the process of writing, which is generally considered as one of the themes related to postmodern metafiction writing. He also adopts the postmodern intertextuality in his writing practice. Those postmodern concerns and strategies confirm his position as a postmodernist.
\end{abstract}

\section{Keywords}

Ian McEwan, Postmodern Strategies, Intertextuality, Atonement, Black Dogs

\section{Introduction}

Ian McEwan, together with Martin Amis is now the best-known and controversial contemporary British novelist. He has been regarded as a serious, objective writer who is interested in writing about obsessive behavior, sex and moral corruption. In 1975, McEwan published his first collection of short stories First Love, Last Rites, which won the Somerset Maugham Award. With the publication of the subsequent collection, In Between the Sheets and his two early novels, The Cement Garden and The Comfort of Strangers, he gained the nickname of "Ian Macabre". The macabre continued to be a feature in his later novels. His third novel showed some significant changes from his earlier works.

As one of the outstanding British novelists of his generation, McEwan has won several awards. Those honors and awards have confirmed his position at the forefront of the contemporary British literary world, and have ensured him a niche in the British literary pantheon.

The contemporary literary field is permeated with all kinds of experimental genres of novels; postmodern novels are one of the most influential ones, with the unique techniques of postmodern narration. Like many 
writers of this age, "McEwan was strongly influenced by the postmodernist techniques of contemporary novelists such as Irish Murdoch and John Fowles in England” (Lynn, 2010).

Many postmodern novelists feature metafiction or "historiographic metafiction" and intertextuality in their writings, Ian McEwan is of no exception. The settings of McEwan's The Innocent, Atonement and Black Dogs carry postmodern features, which have confirmed his position as a postmodern experimentalist. With self-conscious language, the issues of imagination, fabrication, history and storytelling are closely connected with these novels. McEwan's recent novels always carry the features of metafiction and the writer is consciously or unconsciously using such kind of devices. It is without doubt that McEwan is an experimentalist in his exploration of metafiction in the framework of the historical novel.

\section{The Problematic Relationship between Fiction and Reality}

McEwan seems to be interested in the relationship between imagination and reality (fiction and reality) in the process of writing, which is generally considered as one of the themes related to metafiction writing. In his novels, McEwan lays great emphasis on the constructive power of imagination on reality and fiction writing, discussing fictionality inexplicitly in the first chapter. Rene Welleck's comments may give some light to the reader's understanding of this issue.

Art is illusion... The recognition of the difference between life and art, of the ontological gap between a product of the mind, a linguistic structure and the events in real life which it reflects, does not and can't mean that the work of art is mere empty play of forms, cut off from reality. The relation of art to reality is not as simple as older naturalistic theories of copying or "imitation" or Marxist "mirroring" assumes. "Realism" is not the only quarters of the world's literature. It minimizes the role of imagination, personality "making”... (Welleck, 1963).

The relationship between art and fiction is complex, as the theory of writing is developing with the time. On one hand, the gap between imagination and fiction is hard to overstep. On the other hand, "reality" is to some extent "fictional" or "imagined" and can be understood through an appropriate "reading" process, so there is concord between them. Thus, metafiction does not give up the "real world" for the mere pleasure of the imagination. By showing us how imagination creates a new world, the metafictionist is indicating that composing a novel is no different from composing "one's reality".

McEwan's Atonement is a novel about storytelling. The writer focuses on issues like writing, imagination, history and the nature of truth. Thus, imagination plays a vital role in this novel, helping the story develop into the final incident. The issue of imagination is best represented by the protagonist and underlying writer, Briony, a 13-year-old girl embedded with a wild imagination.

McEwan once said writing fiction is about showing the possibility of what it is like to be someone else. It is the basis of all sympathy, empathy and compassion. Cruelty is a failure of imagination. The novel starts with the central character Briony Tallis, the younger daughter of the Tallis family who is "possessed by a desire to have the world just so" (McEwan, 2007). She wrote her first play at the age of eleven, and could not have been held back from her writing.

The fictionalized depiction of the fountain scene is her first misinterpretation and lays the basis for the subsequent illusions. Her imagination and passion for writing blind her to the truth, to the fact that Robbie and Cecilia are real people as she is, instead of fairy tale figures. Consequently, she misinterprets what she is seeing and turns an accidental event by the fountain into a so called blackmail. Looking from the window, Briony sees Cecilia and Robbie standing by the Triton fountain. She tries to interpret the scene and add meaning to this event, but her interpretation is definitely wrong. At the very beginning, Briony reads the scene in the perspective of folk tales, that is to say, this should be a proposal of marriage, just as the humble woodcutter did in her tale. Then she passes over the boundary of romance and steps into realism.

Briony assumes that Robbie is commanding Cecilia to undress by "imperiously" raising his hands. Meantime, she is also wondering "what strange power did he have over her? Blackmail? Threats?” (48) Briony's idea is seemingly developing from a child's point-of-view to a mature one.

She intends to write the scene from three points of view: her own, Robbie's and Cecilia's. She meditates that there is no absolute meaning in an event, but only meaning from two different people. Unfortunately, she can not distinguish her childish thoughts from the reality, regarding Robbie as a potential danger to her sister. And her 
construction of the event from what she has seen is partial and dangerous, for she has little experience of the world. Although Briony is actually innocent, she turns out to be terribly thoughtless and cruel, not qualified to be a writer.

The twisting of life by Briony's imagination leads to a terrible disaster which changes the destiny of Robbie, Cecilia and even herself, which makes her atone for the rest of her life. Briony interprets events according to her own will, and sees what she expects to see. She believes in symmetry, forbidding any stories being violated in real life. She has been composing stories with the scene at the fountain and the incident in the library, not realizing the serious consequences she will bring about.

By relating Briony's fantasy and imagination and a series of misunderstandings resulting from them, this novel explores the problematic relationship between life and fiction. Briony misunderstands, misinterprets, and misconceives the life of others through imagination, and blurs the line between fact and fiction.

\section{The Overlapping of History and Fiction}

Contemporary British writers, especially those in the last two decades, are interested in the description of history, and their works are generally regarded as "new historical novels". Robert Macfarlane once commented that "the questions of how the past is represented in language have become the central obsession of British fiction over the past three decades” (Hidalgo, 2005). Some representatives of this trend are A. S. Byatt, John Fowles, and Ian McEwan.

McEwan's Atonement is a historical novel with its setting ranging from 1935 through the Second World War to the recent days. In the novel, the fates of individuals are intermingled with the verisimilitude of history and society. And history, fact and fiction are knitted into the narrative framework.

In response to Robert Macfarlane's review of Atonement for The Times Literary Supplement, Pilar Hidalgo observes that "the tendency has been far more marked in the 1990s and the early 2000s, when British novelists have engaged with the past in ways that have little to do with the traditional forms of historical novel or with the self-conscious parody of the historicgraphic metafiction” (Hidalgo, 2005). Since Atonement is a new historical novel with elements of realism and metafiction, apparently influenced by the trend of postmodenism, some related conceptions must be taken into consideration. It may be stated with some degree of safety that without some understanding of postmodernism and historicographic metafiction, there can be no real and full understanding of McEwan and even the contemporary British literature. In some way, the construction of Atonement itself is a reflection of the writer's understanding or meditation on contemporary fiction writing, an experimental novel on history and metafiction.

In terms of the relationship between history and fiction, Aristotle states that the historian could speak only of what has happened; the poet, on the other hand spoke of what would or might happen. To Linda Hutcheon, "historiographic metafiction" as part of the phenomena of metafiction and a variant of historical novel, reveals the best combination of history and fiction. By labeling it, she means those popular novels which are both selfreflective and paradoxically also lay claim to historical events and personages. Such novels redefine the concepts of "reality", "history" and "truth" and blur the line between fiction and history.

Ian McEwan's Black Dogs "critically addresses postmodern notions of history and the self, precisely by employing them in order to show up their limitations". The novel is full of the historical issues, such as the postwar British communism, the Second World War and the fall of Berlin wall. In Black Dogs, one of the main characters offers his understanding about World War II. He ponders

... the recently concluded war not as a historical, geopolitical fact but as a multiplicity, a near-infinity of private sorrows, as a boundless grief minutely subdivided without diminishment among individuals who covered the continent like dust, like spores whose separate identities would remain unknown, and whose totality showed more sadness than anyone could ever begin to comprehend (McEwan, 1992).

Atonement is different from Black Dogs in terms of the war. It is a novel with a broad historical significance. The love story between Robbie and Cecilia interweaves with the history, especially of the Second World War, making it a modern romantic epic. The story is mainly composed of three parts and an epilogue, which chronologically corresponds to the time span of the story line. The first part focuses on the pre-war rural life at the Tallis family mansion in England and about the sin committed by Briony. The second and third parts depict the events during wartime, with the former focusing on the retreat from Dunkirk and latter focusing on the London 
hospital. Here McEwan turns his subject to the Second World War which is "the great ignored, unignorable subject for a generation of English novelists, who have on the whole preferred to deal with it obliquely, as Kazuo Ishiguro did in “The Remains of the Day". In fact, McEwan has taken the darkness of the Nazi Regime in his Black Dogs, which also has a connection with war as discussed earlier.

So in Atonement, McEwan combines the fates of the individuals with the historical background of World War II, placing great importance to the retreat at Dunkirk, which is the key element of part two and three. Just as Hermione Lee observes in an article, Atonement has a political perspective in that it deals with both the literary history and the Second World War.

In the novel, McEwan combines historical fact and fiction, blurring the line between fiction and history, and creates a new whole by narrating the past in a new way. In some way, McEwan's narrative has some connection with Fowles's The French Lieutenant's Women, in which the juxtaposition of the past and fiction is obvious everywhere. In Atonement, McEwan takes the history of Dunkirk into consideration, exhibiting a paradoxical relationship with the past, which is mythologized and glorified in many artistic depictions.

McEwan makes a detailed depiction of the horrible sight of the war. At the same time, he makes the reader meditate on those details of history, about which his novel may offer more information than those historian. So here fiction provides a number of possibilities ignored by the historians. Those possibilities, whether they are real history of the past or not, are no less real in his fictionalized world.

McEwan skillfully combines the scene of retreat to Dunkirk with his storytelling, blurring the line between fact and fiction. In fact, many of the depictions about war are drawn from or at least influenced by his father's experiences during the Second World War. And the scene of the leg on the tree comes from a picture taken from Bosnia. So sometimes, the writer of fiction is a particular kind of historian, for in his fictional world, history becomes fictionalized. The writer's design of plot and structure reflects his attitude towards history. The examination of the novel itself makes the reader ponder the story's relationship with the past, between fiction and history.

\section{The Employment of Intertextuality}

Postmodern novels utilize various devices to help the reader appreciate the theory and practice. Apart from the other traits, it often employs intertextual references and allusions by discussing and presenting fictional works to achieve its style of writing.

Atonement is a self-aware novel in terms of the many literary precedents and works it mentions and discusses. In fact, Ian McEwan has consistently drawn attention to the status of his fiction as an artifact in his early works. By alluding to or parodying traditional literary genres, he makes the reader pay more attention to the presence of a self conscious narrator.

He has described each of his early stories as "a kind of pastiche of a certain style $[\cdots]$, its origins were always slightly parodic” (McEwan, Hamilton 17). Similarly most of his novels, according to him, allude in some way to existing genres-The Cement Garden is “an urban Lord of the Flies” (Smith, 69); The Innocent added to and subverted the spy genre (McEwan, Hunt 47); The Comfort of Strangers draws on the sinister setting of Venice established by Thomas Mann in Death in Venice; his play for television, The Imitation Game, was indebted to Virginia Woolf's Three Guineas (Haffenden, 175); and “Amsterdam is an Evelyn Waugh tribute novel”, McEwan told Ambrose Clancy (E1.) (Brian, 2004).

Even in his most recent novel, Saturday, McEwan alludes to some literary figures like Marthew Arnold, whose poem "Dover Beach" is quoted in the novel. So it is natural to notice that McEwan draws on many writers in his novel, such as Jane Austen, Henry James, Elizabeth Bowen, and Virginia Woolf. In the reviews of Atonement, many critics have made comments on Atonement's connections with some specific fiction, namely L. P. Hartley's The Go Between, which is also about a child's misunderstanding of adult sexual relationship in a country house, together with Henry James' What Maisie Knew. In terms of history and mystery, this novel has some connection with Possession by A. S. Byatt and The French Lieutenant's Woman by John Fowles. The recognition and appreciation of those literary references give the novel a richer meaning and enable the reader to read in a productive way.

At the very beginning, McEwan chooses a quote from Jane Austen's novel Northanger Abbey as an epigraph. The thoughtful reader can not help wondering what this epigraph serves for, what the purpose is. Possibly, this 
salient intertextual reference serves as a guide to the reader. As Finney indicates, like Austen, McEwan is playing with the reader, making use of their spontaneous and naïve expectations and finally leading them into a wrong judgment.

McEwan has sometimes mentioned Atonement in the interview as his "Jane Austen" novel. It is apparent that Briony is a "Jane Austen Heroine" in the way that she bares some resemblance to Morland. In addition to this, Atonement also has some other connections with Jane Austen. The first part of Atonement takes the country house as its background and is presented in a traditional realistic manner. It is well known that living in the countryside, Jane Austen restricted her subject matter to a small world: the quiet, middle class circle in provincial surroundings. Her arts of vivid characterization and psychological penetration make her the cult figure in twentieth century English literature.

Indeed, the first notable country-house novels were written by Jane Austen, namely, Mansfield Park, Sense and Sensibility. The Tallis house scenes securely rooted in traditional realistic literature, with basic elements like plot, character and the country house motif. At the end of the novel, the Tallis house has been turned into a hotel with the new name of "Tilney", which takes the reader back to the quotation of Northanger Abbey.

Later, Briony's melodrama, The Trials of Arabella is another allusion to Samuel Richardson's Clarissa. The protagonist in Briony's melodrama, Arabella, is the name of Clarissa's sister. The choice of name in the drama is not accidental but of some artistic value. This will naturally remind the reader of the novel Clarissa and the treatment of sentiment. In fact, McEwan has mentioned this novel through the description of Cecilia's afterschool life. When Cecilia graduates from Cambridge, she stays at home and reads Clarissa to entertain herself. During their conversation, Cecilia uses the word "boring" to comment on this book, and expresses her interest in Fielding who is psychologically crude in the eyes of Robbie. To a certain extent, Cecilia's preference for Fielding over Richardson includes some sexual explicit message, for the works of Fielding may indicate a taste for the blood and sensual.

In addition to this, the rape scene may make the reader reflect on A Passage to India by E. M. Foster. During a trip to the Marabar Caves, the white British schoolmistress Adela Quested falsely accuses Dr. Aziz, an Indian Physician of attempting to rape her. There are many parallels between the two novels. Both of them make a description of the rape scene and its aftermath. Similarly, Adela, like Briony commits a sin which exerts enduring influence on the victim. Aziz, just as Robbie, is less likely to be believed, becoming a victim of discrimination. The difference is that the former is prejudiced by racial discrimination; the latter is a victim of class consciousness.

In Paris Review, McEwan has admitted the influences of L. P. Hartley's The Go-Between on Atonement by saying that "L. P. Hartley's The Go-Between made a huge impression on me". In the interview with David Wiegand, McEwan said that

By the time I was at boarding school-a very unelite place-I was reading very intensely. In fact, one of the books I read at the age of 12 that formed the seed for "Atonement" was "The Go-Between". I was completely taken by that, partly because it was set in a country house and my boarding school was in a country house (Wiegand, 2002).

Atonement makes another literary allusion to Margaret Atwood's The Blind Assassin. James Harold, argues, the two novels are similar in terms of characterization, settings and plots and the narrative arts. Both of the works take advantage of the reader's innocence and employ a tactical trick in the narration, which is the application of the unreliable narrator. When it comes to the unreliable narrator, Atonement also bears resemblance to Kazuo Ishiguro's Booker Prize Winner, The Remains of the Day, which turns out to be incredible in spite of its seeming objectivity.

McEwan weaves some other figures in literature into the fabric of Atonement, which highlight its artificial nature. When Robbie reflects on his life in the prison, he reveals the way Cecilia and he communicated with each other under the prison's censorship. They write in codes, which is mostly based on the books and figures in literature. Robbie compares himself and Cecilia with the literary figures he used in the letter such as Tristan and Isolde, Troilus and Criseyde, Venus and Adonis, the Duke Orsino and Olivia, and so on so forth, among which only Emma and George Knightley from Jane Austen's Emma have a happy ending. Despairingly, he even makes a reference to Prometheus, chained to a rock, suffering from life there.

The irony, like descriptions of Briony's melodrama scene and others, is obvious in the novel, discriminating the writer's quotations as intertexts instead of sources. "Both Kristiva and Jacque Derrida argue that any text 
seen as intertext entails productivity”. That is to say, the intertexts which Atonement related render more meaning to the original text and make it more productive in many ways. It is safe to draw the conclusion that the application of the intertextuality renders the novels of McEwan more aesthetic significance and postmodern elements.

\section{Conclusion}

It could be stated that McEwan makes a tentative writing of the "postmodern novel" with his unique thematic concern and postmodern techniques. The writer is concerned with the postmodern themes. He not only focuses on the dark issues like violence, sex and immorality, but also probes into the problematic relationship between fiction and reality, history and fabrication. Meantime, he adopts the postmodern intertextuality in his experimental writing practice.

As a matter of fact, McEwan's major novels approximate the traditional narrative mode of realistic novels, but deep down there are considerable postmodern elements and techniques. McEwan successfully performs his own understanding of fiction writing. In his eye, the significance of fiction writing lies in that when the book is revealed, it will show the reader its own rules and the way of writing, which is, without any doubt, an appropriate illustration of postmodern writing.

\section{Acknowledgements}

This paper is under the project of Postmodernism in Ian McEwan's Major Novels (2011S12). And it is sponsored by the English Literature Teaching Team of Baoding University (Td20090204). I am deeply indebted to all the team members, who offered invaluable advice and comments.

\section{References}

Brian, F. (2004). Briony's Stand against Oblivion: The Making of Fiction in Ian McEwan's Atonement. Journal of Modern Literature, 3, 68-82.

McEwan, I. (1992). Black Dogs. UK: Vintage.

McEwan, I. (2007). Atonement. New York: Anchor Books.

Hidalgo, P. (2005). Memory and Storytelling in Ian McEwan's Atonement. Critique: Studies in Contemporary Fiction, $2,82$.

Welleck, R. (1963). Some Principles of Criticism. In The Critical Moment (pp. 41-51). London: Faber \& Faber.

Wiegand, D. (2002). Getting Rid of the Ghosts. San Francisco Chronicle, 10 March 2002: M.2. 
Scientific Research Publishing (SCIRP) is one of the largest Open Access journal publishers. It is currently publishing more than 200 open access, online, peer-reviewed journals covering a wide range of academic disciplines. SCIRP serves the worldwide academic communities and contributes to the progress and application of science with its publication.

Other selected journals from SCIRP are listed as below. Submit your manuscript to us via either submit@scirp.org or Online Submission Portal.
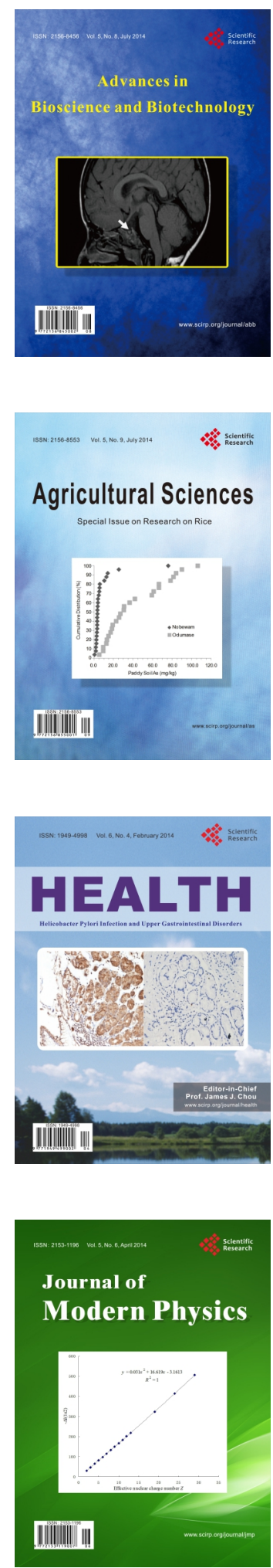
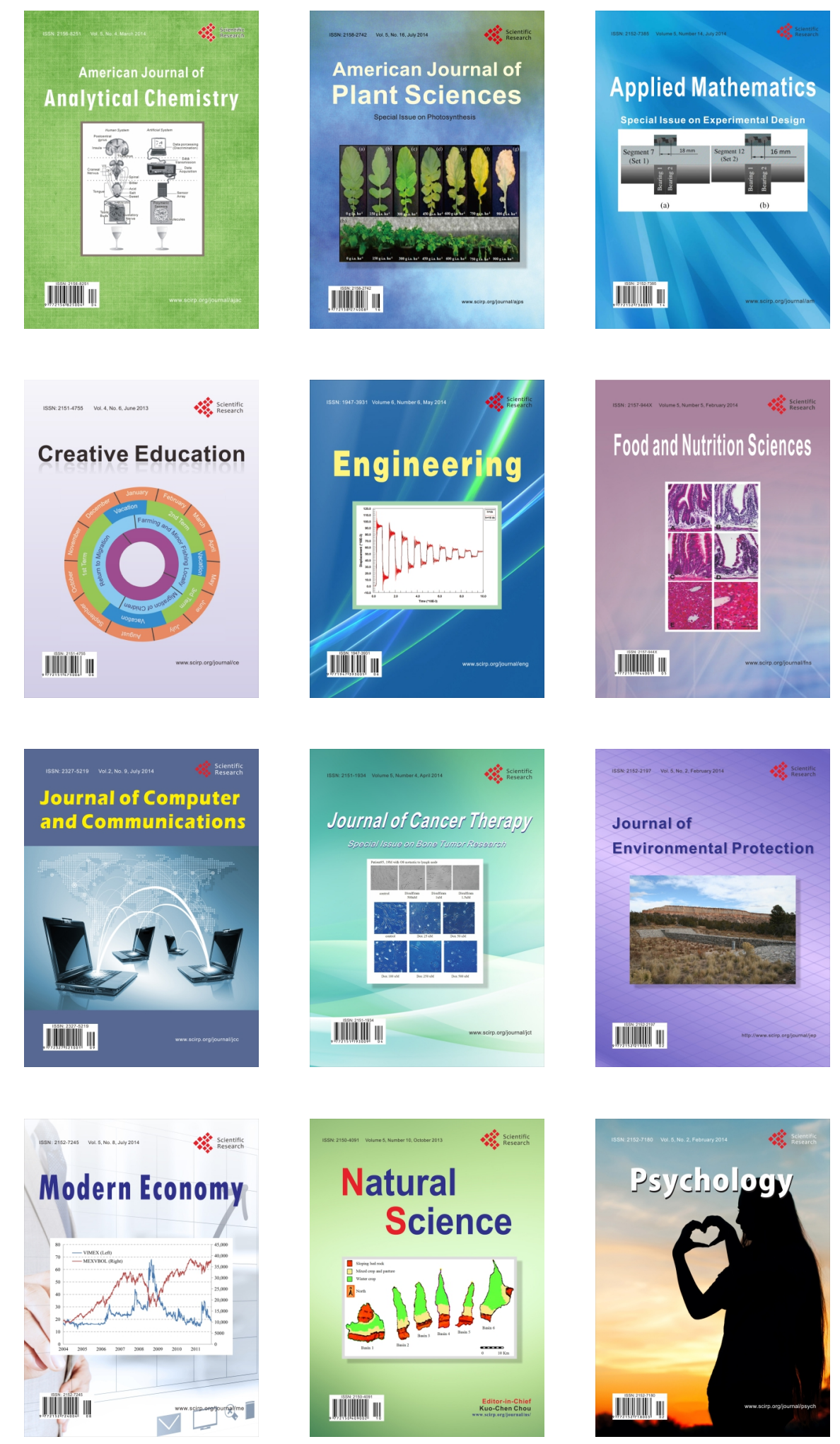